\title{
THE PROBLEM OF COMPETITION ON REAL ESTATE MARKET ON THE EXAMPLE OF THE LOCAL HOUSING MARKET IN OLSZTYN
}

\author{
Oksana Kuryj-Wysocka, M.Sc. \\ Faculty of Geodesy and Land Management \\ University of Warmia and Mazury in Olsztyn \\ e-mail: oksana.wysocka@uwm.edu.pl
}

\author{
Radosław Wiśniewski, Assoc. prof., PhD \\ Faculty of Geodesy and Land Management \\ University of Warmia and Mazury in Olsztyn \\ e-mail:danrad@uwm.edu.pl
}

\begin{abstract}
In the economic theory, competition is considered to be a fundamental principle of the free market. Due to the competition, customers get lower prices, better service quality, more and more choices. The competition in the real estate market is a very important factor in its development. Buying or selling real estate is often one of the most important financial transactions, which require the purchaser. With the reference to the above, the participants of the real estate market need to analyse a number of transactions and do a detailed understanding of the market before making a decision and finding a deal that meets all the expectations which will not be diverging significantly from remaining offers functioning in the given area of the market. The phenomenon of competition is very advantageous for buyers of a real estate, because it shows a wide range of various possibilities which one should consider before making a final choice.

Times of crisis trigger a tendency of the growing competition in the property market, what results in a decrease in real estate prices. This article brings up the issue of price and non-price competition on the real estate market and the influence which it exerts on the decision of the purchaser. The aim of this paper is to present the phenomenon of the competition at three levels (levels), by examining what relationship occurs between the entities functioning on the market, what occurs between entities and objects, and how the entities, i.e. individual real estate, compete with each other. This study will be conducted with methods of statistical analysis of the market, however Herfindahl-Hirschman Index will be used to measure competition on the local real estate market.
\end{abstract}

Keywords: competition, real estate market, Herfindahl-Hirschman Index.

JEL Classification: D40, R30.

Citation: Kuryj-Wysocka O., Wiśniewski R., (2013), “The problem of competition on real estate market on the example of the local housing market in Olsztyn", Real Estate Management and Valuation, vol. 21, no. 1 pp. 69-76.

DOI: $10.2478 /$ remav-2013-0009.

\section{Introduction}

A large supply of housing with limited effective demand caused exacerbating competition on the property market. Ordinary advertising, housing plans or good visualization are more often insufficient tools to attract buyers. Investors are able to respond immediately to any novelties in order to carry out incredible advertising campaigns, which are designed to highlight a particular property (investment) from the market. 
Currently, the Internet is an important tool in the real estate transaction, thanks to which it is possible to reach buyers and sellers directly. It is through the websites, we learn about the planned or carried out investments, as well as about offers of the purchase or the sales of a real estate. In addition, companies operating in the real estate market are trying to get customers in a variety of ways, for example, they expose their brand hoping that the knowledge of the company on the market, developed in recent years will help them in the current sale, however the developers often do not reveal the price of the given property, which may result in the larger number of inquiries and, consequently, help to establish contact with a potential buyer.

A major problem is the fact that, not all competitive behaviours are conducive to the development of the free market. There are actually the market practices which in significant way reduce or affect the development in the given sector. Real estate transactions depend on a variety of potential restrictions of competition, which may exert a significant impact on buyers. Due to the limited quantity of transactions and the large capital, the impact of anti-competitive activities in the sector may have greater value than in most other sectors of the market.

\section{Meaning of competition in the real estate market}

The competition is a phenomenon characterized by certain types of relationships between entities. In order to compete successfully, that is, despite the obstacles created by the competitors to achieve one's targets, it is necessary to be competitive (STRUŻYCKI 1998, p. 173). Stankiewicz (STANKIEWICZ 2005, p. 19) presents one of the definitions of competition phenomenon, which states that "competition is called the phenomenon, when participants compete with each other in the aspiration for similar purposes, which means that the actions taken by some people in order to achieve specific objectives, hinder (and sometimes even make impossible) to achieve the same goals by others." The competition is also defined as "the act or the process of individuals seeking benefits to which at the same time, under the same conditions and rules other people apply to." Its essence is based on the elimination of competitors acting in the same industry and gaining their customers (NoGA 1993, p. 9). The concept of competition in the broadest meaning represents one of the OECD definition, which says that "competitiveness is the ability of both companies, industries, regions, nations or supranational groups to cope with international competition, and to provide a relatively high rate of return from applied production factors and a relatively high employment on a sustainable basis "(STANKIEWICZ 2005, p. 36).

However, none of the listed definition does not exactly reflect in the real estate market, which is characterized by certain specific features. Therefore, this article presents a slightly different (innovative), and unprecedented in the economic theory approach to the competition. For the needs of the real estate market there are three planes of this phenomenon distinguished, e.g., competition between market participants, competition between objects (individual real estate) and indirect competition, occurring between the entities and objects of the real estate market. Various factors, which will be discussed in detail later on in the article, influence the competition on the individual levels.

\section{Competition between market participants}

The rivalry between the real estate market participants depends on the competitive position of the companies operating in this market. In this article, the issue of rivalry between participants in the real estate market has been presented on the example of property developers, working on the real estate market in Olsztyn. The competitive position of the property developer or a building enterprise is a multi-dimensional category, which is determined by a combination of factors, such as market share, a scope of the influence on the market, a scale of operation, applied technologies and technical abilities, knowledge and adaptability (GARBARSKI 1997, p 38). A competitive advantage of a participant is a reflection of his competitive position on the real estate market. It is interpreted differently, depending on the subject, the point of view and the aim of determining. Generally, it is possible to determine the competitive advantage from a point of view of the given property developer or from a perspective of flats buyers. The competitive advantage, from the point of view of the developer, is its unique position in the sector compared with competitors, which allows to achieve more than average profits and to overtake the competition (ŻABIŃSKI 2000, p. 202). The competitive advantage depends on the housing stock which a company is able to create for its customers. From a buyer's point of view the competitive advantage is a subjective category and it means the higher sum of the price offered by the 
developer.

A measure of concentration, such as participation of the largest entities on the market or the Herfindahl index - Hirschman (abbreviated HHI), is taken for traditional measures of the competition level. The decrease in concentration measures reflects the increase in the level of competition, where the increase of concentration indicates the decrease in competition. In the economic theory, $\mathrm{HHI}$ is defined as the sum of the share squares in the sale of all enterprises acting on the market. The decrease in the Herfindahl-Hirschman index entails a decrease in strength and the increase in the competitiveness of producers, however when the index increases it entails the other way round. In practice, $\mathrm{HHI}$ is often calculated by summing the squares of the market shares, expressed in a percentage.

Table 1

The participation of individual developers in the market of Olsztyn

\begin{tabular}{|c|c|c|c|c|c|}
\hline $\begin{array}{l}\text { Name of } \\
\text { developer }\end{array}$ & $\begin{array}{l}\text { Realized } \\
\text { investments }\end{array}$ & $\begin{array}{c}\text { Date of } \\
\text { completion }\end{array}$ & $\begin{array}{l}\text { Number } \\
\text { of flats }\end{array}$ & $\begin{array}{c}\text { Average } \\
\text { price } \\
\text { in } \mathrm{zl} / \mathrm{m}^{2}\end{array}$ & $\begin{array}{c}\text { Participation in } \\
\text { market }\end{array}$ \\
\hline \multirow[t]{3}{*}{ Arbet } & District „Leśna” & finished & 348 & 5150 & \multirow{3}{*}{$348 / 2195=0.159$} \\
\hline & Warmia Towers & in completion & 196 & 6200 & \\
\hline & District „Gardena" & III/VI 2013 & 400 & 4200 & \\
\hline \multirow[t]{3}{*}{ Mas - Bud } & Piotrowskiego & XII 2012 & 70 & 3868 & \multirow{3}{*}{$163 / 2195=0.074$} \\
\hline & $\begin{array}{l}\text { District } \\
\text { „Nad Łyną" }\end{array}$ & finished & 63 & 3925 & \\
\hline & Houses near Łyna & finished & 30 & 3056 & \\
\hline \multirow[t]{2}{*}{ Rombud } & Parkowe Wzgórze & finished & 51 & 6200 & \multirow{2}{*}{$131 / 2195=0.060$} \\
\hline & Wichrowe Wzgórze & finished I stage & 80 & 4150 & \\
\hline Novdom & „Villa Solaris & finished & 95 & 4712 & $95 / 2195=0.043$ \\
\hline Polnord & „Tęczowy Las" & finished & 187 & 4100 & $187 / 2195=0.085$ \\
\hline \multirow[t]{2}{*}{ WPB } & Terraced houses & in completion & 24 & 3300 & \\
\hline & Augustowska & finished & 56 & 4420 & $56 / 2195=0.026$ \\
\hline \multirow[t]{2}{*}{ IPB } & District „Przylesie” & finished I stage & 96 & no data & \multirow{2}{*}{$296 / 2195=0.135$} \\
\hline & District B. Laszki & finished & 200 & no data & \\
\hline \multirow{2}{*}{$\begin{array}{l}\text { OPB } \\
\text { Development }\end{array}$} & „Browary Park” & finished & 207 & 5200 & \multirow{2}{*}{$207 / 2195=0.094$} \\
\hline & Versal XXI & in completion & 150 & 5500 & \\
\hline \multirow[t]{2}{*}{ Ekobud } & Jagiellońska & IX 2012 & 236 & 4850 & \multirow{2}{*}{$269 / 2195=0.123$} \\
\hline & Hanki Sawickiej & X 2012 & 33 & 5000 & \\
\hline $\begin{array}{ll}\text { Na } & \text { Skraju } \\
\text { Miasta } & \\
\end{array}$ & District „Parkowe” & II kw. 2013 & 142 & 6150 & \\
\hline $\begin{array}{l}\text { T.J.M } \\
\text { Development }\end{array}$ & Willa Patio & XII 2012 & 45 & no data & $45 / 2195=0.021$ \\
\hline MDC & Janowicza/Mroza & finished & 333 & 4425 & $333 / 2195=0.152$ \\
\hline CL Invest & Terraced houses & in completion & 18 & 3423 & \\
\hline GI Projekt & Terraced houses & in completion & 11 & 3365 & \\
\hline $\begin{array}{l}\text { Other } \\
\text { developers }\end{array}$ & No data & finished & 65 & no data & $65 / 2195=0.030$ \\
\hline
\end{tabular}

Source: on the basis of own study.

In order to illustrate the level of competition in the real estate market of Olsztyn, a research was carried out, connected with the market offer amongst leading developers investing in Olsztyn in 20112012. The study included fourteen companies operating in the city, which were analysed in terms of the conducted investments, in order to count the shares of individual developers. The market share of each enterprise was calculated on the basis of completed units, during the analysed period, by each developer in relation to the total number of dwellings completed in Olsztyn in 2011-2012 (according to data from the statistical office in Olsztyn during the analysed period 2195 apartments has been completed).

The results of the study are presented in table 1. 
At the table 1 there were shares calculated of those developers whose investments were made during the examined period. The studies did not included developers, whose investments are still ongoing. The next stage of the research was to sum the squares of the individual shares. Based on the above data, the following results were obtained: the Herfindahl - Hirschman Index HHI = 0.1107, whereas the concentration ratio (defined as the sum of the squares of the market shares in percent) $\mathrm{HHI} \%=1107$.

The received results prove a moderately high level of concentration on the researched market of the real estate in 2011-2012. If the above rate was lower than 1000 it would prove a lack of concentration on the market, whereas the value above 1800 would indicate a very high concentration and equally high competition in the given market. Based on conducted examinations it is possible $t$ state that during the analysed period the level of competition among developers on the Olsztyn real estate market was quite high, where Arbet Enterprise had the leading role on this market. Individual shares of other developers are presented in the following chart.

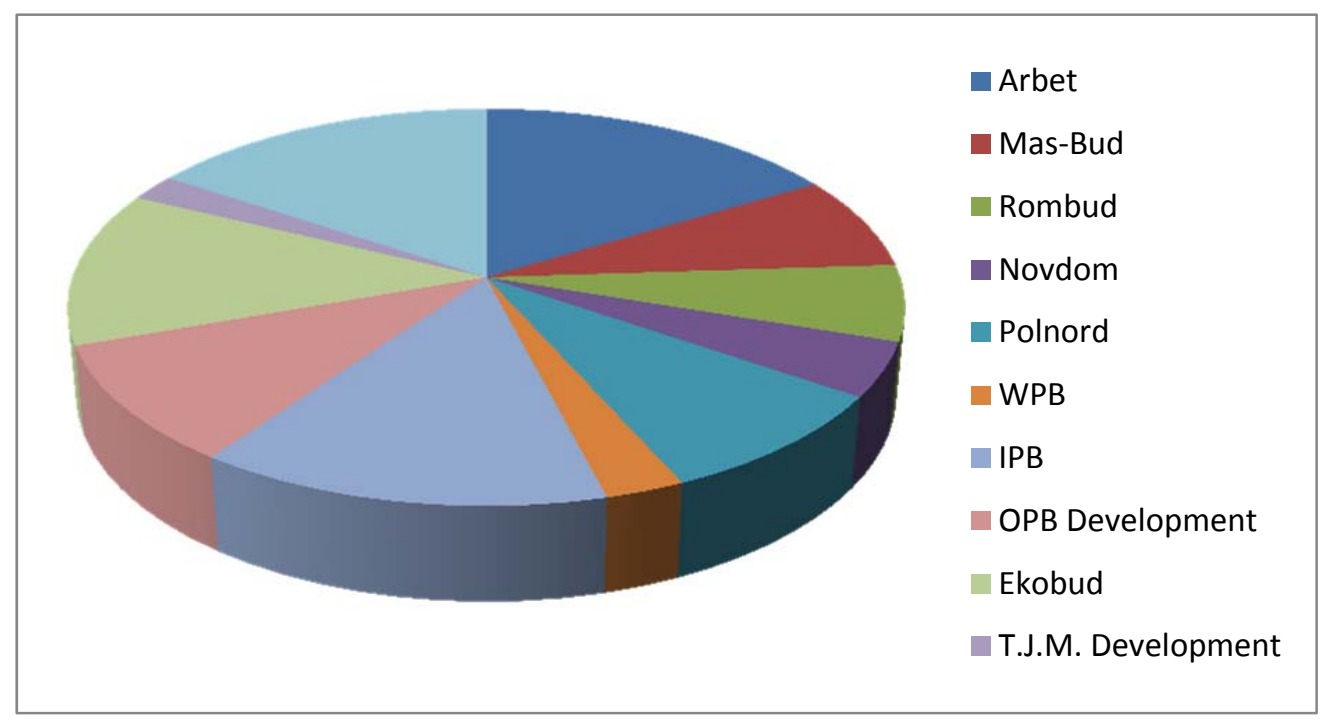

Chart 1. Participation of some developers in the market in 2011-2012. Source: on the basis of own examinations.

A price fight, which can accept different forms, is one of the indications of competition between real estate market participants. Some developers when purchasing homes offer a variety of bonuses, for example, discounts up to $20 \%$ off the premises, storerooms or free parking spaces. Developers of emerging investments prefer to make the transactions at much lower prices, so that they defrost capital and they do not incur any fixed costs of maintaining the property, such as maintenance fees, rent or property taxes. This gives developers the possibility of starting new investments and trading the capital. Flexible pricing is the most effective way to sell real estate with the current level of competition. The study shows that the competition in the real estate market in Olsztyn is so big that without aggressive pricing policy recruiting the customer could take months. The chart below shows an example of the investment and the average prices of $1 \mathrm{~m}^{2}$.

Analysing the following chart it is Parkowe". possible to notice that the investments located in the city centre with the high finishing standard are characterised by the highest prices around PLN 6200/ $\mathrm{m}^{2}$ that is "Warmia Towers", "Parkowe Wzgórze", District "Lower prices around PLN 5000 / m 2 can be seen on the estate Zatorze, which is located in close proximity to the main railway station of the city. However, the most varied prices from PLN 3800 to 4800 / m ${ }^{2}$ exist on the Jaroty district, which may be due to differences in the availability of communication between areas located in the centre of the estate and those located in peripheral areas which have restricted access to public transportation. To sum up, the price of the investment is affected by many factors, but it is mainly determined by the factors of the location and prestige of the district (KURYJ O. and KURYJ J. 2009, p. 36). 


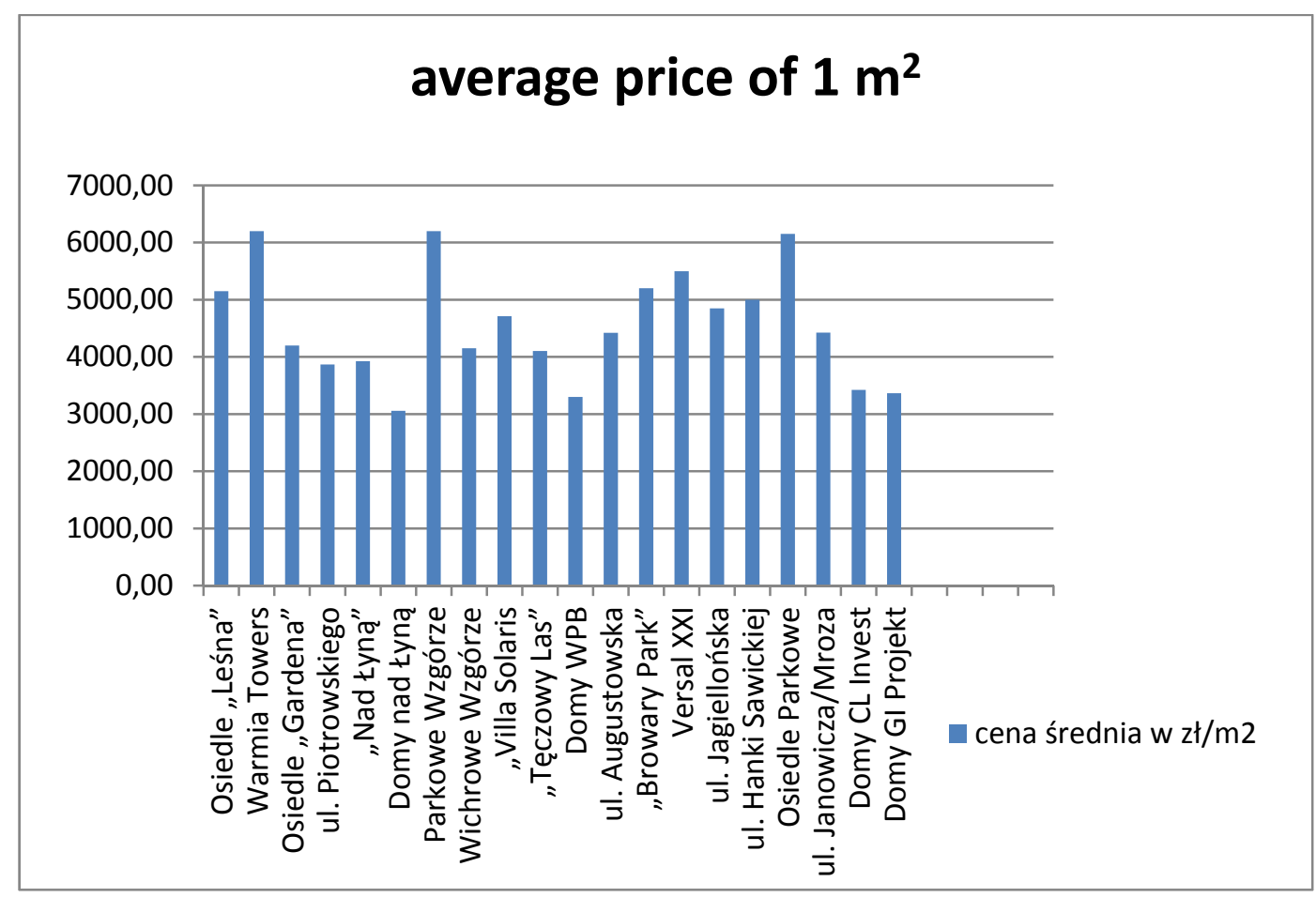

Chart 2. Average prices of selected investments in Olsztyn. Source: on the basis of own examinations.

\section{Competition between participants and objects (properties)}

A large number of new homes currently available on the market and the reducing area of land within the administrative boundaries of a city cause the investors to compete for a ground in the best location. However, before an investor decides to purchase the given real estate he must conduct a detailed analysis of the project. The point of departure for an initial analysis is to assess the attractiveness of locations for potential buyers. The majority of offers for sale available on the market have a complex character, and their transactions are not considered to be simple, therefore every investment requires the examination of its potential, threats, strong and weak points, as well as all the circumstances associated with the preparation, realisation and sale. Stage preceding the decision about taking the investment requires a long time and a lot of work, what may cause an interest in the given real estate of other investors and sharpen competition in a specific area.

The phenomenon of competition between the entities and objects in the real estate market has been analysed on the basis of data obtained from the developers and the planned investments in the city of Olsztyn and surroundings. Data is presented on the map, where the individual numbers indicate subsequent housing projects that have been planned by the investors in 2011-2012.

The map below shows that most of investments are planned for the estate Jaroty - 11 of 44 total investment, what constitutes about $25 \%$ of the planned investment, the city centre is on the second place - 7 investments, about $16 \%$, and Zatorze is on the third place - 5 investments, what constitutes about $11 \%$. Remaining results are presented in table 2 .

Based on the given data, it is possible to state that for the years 2011-2012 in the area of Olsztyn and the surrounding area there are 44 investments planned, as a result of which 4,539 flats and houses should be build. From all the investments in the city, those being outside the city i.e. 54 flats and 93 houses, which is $3 \%$ of the total investment, were removed. Thus, the percentages of individual housing estate have been calculated from the value of 4392, which is the number of apartments and homes planned in the area of Olsztyn. The above table shows that the Jaroty housing estate is the leading one according to the planned investments, whereas the city centre housing estate takes the advantage when it comes to the number of planned flats and houses, Zatorze is on the third place in terms of participation in the total number of investments. This study shows which housing estates in the city are mostly taken into consideration by investors. Interest of a particular location may be associated with various factors such as the housing estate fashion, communication accessibility, 
proximity to public institutions, etc. and this can perhaps be identified with the competitiveness of the given housing estate in the context of the entire city.

In comparing to data published by the Statistical Office in Olsztyn, it is possible to notice that only some of the planned investments have been carried out within the specified period of time. According to the announcements of the socio-economic situation of Warmian and Mazurian province, published by the statistical office in 2011 in the city of Olsztyn 957 flats were completed, while in 2012 this number amounted to 1,238 flats, what gives a total of 2195 dwellings completed in the considered period considered. Therefore, the number of flats completed in 2011-2012 represents about $50 \%$ of the planned number of units, which may indicate that some of the investments have not been finished or they resigned from less profitable undertakings..

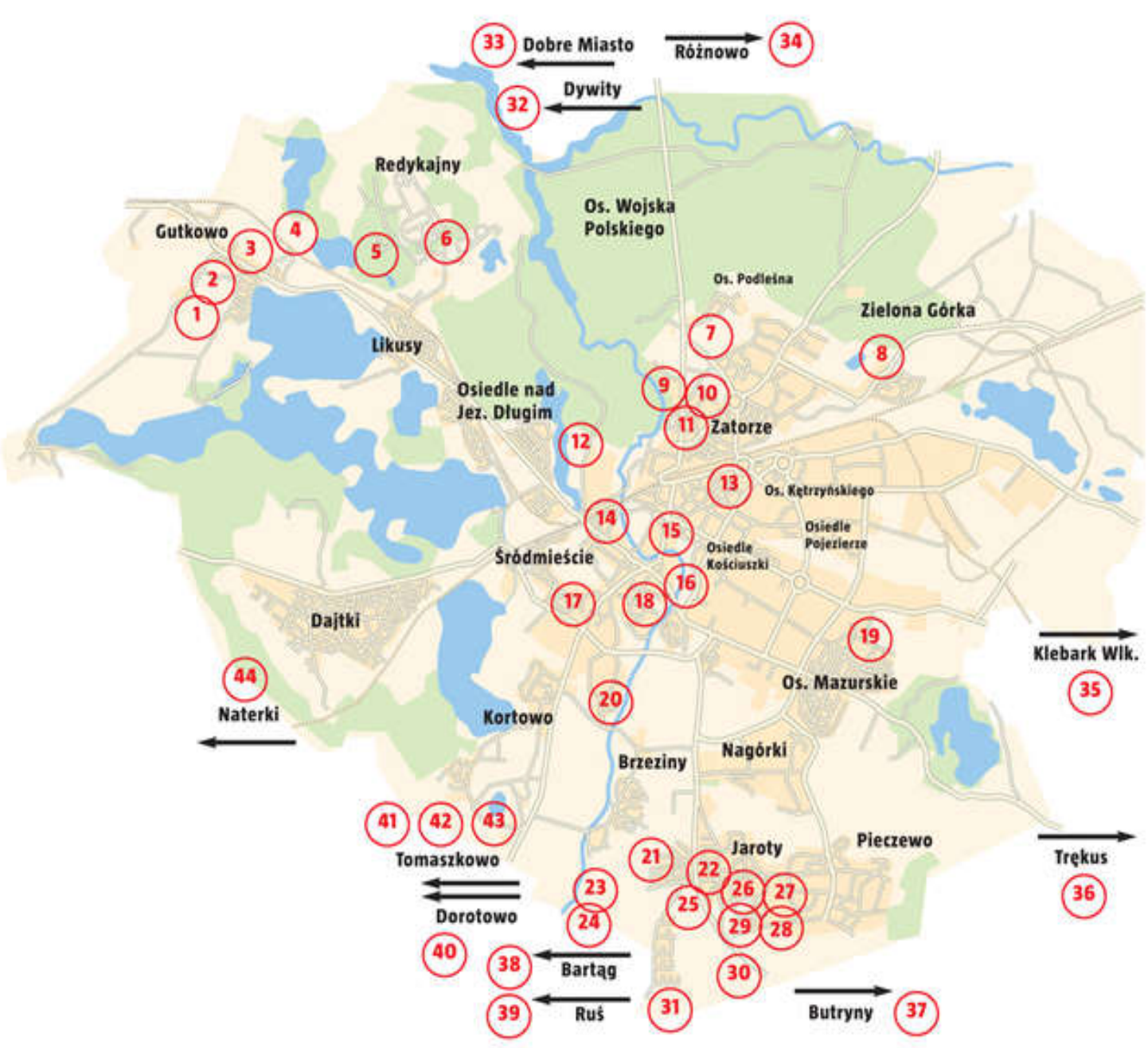

Chart 3. Map of residential Olsztyn and the surrounding area in 2011-2012. Source: own examinations based on data obtained from the developers.

Table 2

Housing projects in various districts

\begin{tabular}{ccccc}
\hline Name of district & $\begin{array}{c}\text { Figures of } \\
\text { investments }\end{array}$ & $\begin{array}{c}\text { Number of } \\
\text { investments }\end{array}$ & $\begin{array}{c}\text { Percentage of } \\
\text { participation }\end{array}$ & $\begin{array}{c}\text { Number of } \\
\text { flats/houses }\end{array}$ \\
\hline Gutkowo & $1-3$ & 3 & 0.8 & $0 / 37$ \\
\hline Redykajny & $4-6$ & 3 & 0.9 & $24 / 16$ \\
\hline Zatorze & $7-11$ & 5 & 26.7 & $1176 / 0$ \\
\hline Śródmieście & $12-18$ & 7 & 34.5 & $1513 / 0$ \\
\hline Os. Mazurskie & 19 & 1 & 1.3 & $56 / 0$ \\
\hline
\end{tabular}




\begin{tabular}{ccccc}
\hline Os. Mleczne & 20 & 1 & 2.2 & $96 / 0$ \\
\hline Jaroty & $21-31$ & 11 & 33.6 & $1448 / 26$ \\
\hline Inne & $32-44$ & 13 & - & $54 / 93$ \\
\hline
\end{tabular}

Source: on the basis of own study

\section{Competition between properties}

The competition between individual real estate can be identified with the attractiveness of the given real estate compared to other properties available on the market. Accepting the above point of reference this competition may be held indirectly through the features of the external environment such as the location of the property, neighbourhood, accessibility, distance from the city centre and the closeness to public institutions. Depending on the needs of the potential buyer both properties can be attractive, the one located near the city centre, but also the one on its outskirts. The competitive advantage of the location of the property is a crucial factor influencing the attractiveness of the investment, but it is not the only criterion (PORTER 2001, p. 403).

The competition between the property can be held also by attributes directly related to the property such as its size, location on the floor, finish standard, condition of the building in which it is located (KURYJ, KURYJ 2009, p. 36; BEŁEJ, KUlESZA, 2013). These attributes may be perceived as positive by some buyers, whereas the others will consider them as negative and only the individual assessment of the given entity allows to determine whether a particular property has all the necessary features which it hold have in his opinion. Despite the functioning of many factors which influence competitiveness (attractiveness) of the property, the price that the buyer is willing to pay for a particular flat or house is an extremely important factor. It is the price which is the main outcome affecting the interest of potential buyers. Low property price may encourage customers and it is often a major factor in making the decision about the choice of housing. However, the higher the price of the property, the offer becomes richer. To sum up, apart from location and physical factors that influence the competition between individual properties there are also external factors: legal and political, which to some extent determine the prestige and security of the given housing estate.

\section{Conclusion}

Analysis of the phenomenon on the example of the competitiveness of the real estate market is highly complicated. As it can be seen from the quoted examinations, in the economic theory there is no clearly established definition which could be reflected in every segment of the market. Undoubtedly, it is correlating with the action of different mechanisms, of which the influence is not equal in each sector. In order to correctly determine the level of competition in the given market, it is essential to conduct a sequence of detailed examinations which will determine not only the degree of concentration, but also the profits and efficiency of enterprises, creating the position of the company on the market.

A large number of flats completed on the property market in Olsztyn in 2012 with reference to the previous year caused that a lot of people are selling existing homes to buy new, for example, in a better location or a higher standard. This contributed to the increase in the supply of homes on the market at the steady demand, which is currently at a very low level. In addition, a large number of ready-to-use units increased competition among real estate developers. A bigger increase in price of the real estate, which is a crucial tool in the competition of gaining the customer, is the result of such rivalry. Nobody knows for how long such downward trend of prices will continue because the pace and competition on the real estate market will depend on both the economic situation of the country and on the politics pursued by the government.

\section{Bibliography}

BeŁeJ, M., KuleszA, S., (2013), Modeling the Real Estate Prices in Olsztyn under Instability Conditions, Folia Oeconomica Stetinensia, Volume 11, Issue 1, Pages 61-72, ISSN (Online) 1898-0198, ISSN (Print) 1730-4237, DOI: 10.2478/v10031-012-0008-7.

BulAN L., MAYER CH., SOMERVILle T., 2009, Irreversible investment, real options, and competition: Evidence from real estate development, Journal of Urban Economics, vol. 65, issue 3, p. 237-251.

GARBARSKI L., 1997, Wybór rynku docelowego przez przedsiębiorstwa w warunkach konkurencji, Marketing jako czynnik i instrument konkurencji, PWE, Warszawa. 
Komunikat o sytuacji społeczno-gospodarczej województwa warmińsko-mazurskiego w grudniu 2011 r., $\mathrm{Nr}$ 12/2011, data publikacji: 27.01.2012, www.stat.gov.pl/olsz

Komunikat o sytuacji społeczno-gospodarczej województwa warmińsko-mazurskiego w grudniu 2012 r., $\mathrm{Nr}$ 12/2012, data publikacji: 29.01.2013, www.stat.gov.pl/olsz

KURYJ O., KURYJ J., 2009, Atrybuty kształtujące ceny lokali mieszkalnych na przykładzie miasta Olsztyna, Acta Scientiarum Polonorum, Administratio Locorum 8(2) 2009, s. $29-40$.

NoGA A., 1993, Dominacja a efektywna konkurencja, SGH, Warszawa.

O'DONNELL S., GEURTS T., 1995, Competition and value-of-service pricing in the residential real estate brokerage market, The Quarterly Review of Economics and Finance, Volume 35, Issue 3, p. 327-332.

PORTER M.E., 1994, Strategia konkurencji, PWE, Warszawa.

PORTER M.E.,2001, Porter o konkurencji,PWE, Warszawa.

QIAN Q., CHAN E., CHOY L., 2013, How transaction costs affect real estate developers entering into the building energy efficiency (BEE) market?, Habitat International, vol. 37, p. 138-147

STRUŻYCKI M., 1998, Konkurencja w zarządzaniu przedsiębiorstwem, Podstawy zarządzania przedsiębiorstwem, SGH, Warszawa.

STANKIEWICZ M.J., 2005, Konkurencyjność przedsiębiorstwa, Budowanie konkurencyjności przedsiębiorstwa w warunkach globalizacji, Dom Organizatora, Torun.

STANKIEWICZ M.J., 2000, Istota i sposoby oceny konkurencyjności przedsiębiorstwa, Gospodarka Narodowa, nr 7-8.

ŻABIŃSKI L., 2000, Przewaga konkurencyjna, PWE, Warszawa. 